\title{
Learning mathematical symbolization: conceptual challenges and instructional strategies in secondary schools
}

\author{
Aprendendo a simbolização matemática: desafios conceituais e estratégias \\ de ensino na escola secundária
}

\author{
Paul Mutodi * \\ ORCID iD 0000-0001-5904-6095 \\ Mogege Mosimege** \\ ORCID iD 0000-0003-4685-3423
}

\begin{abstract}
This paper investigates South African $12^{\text {th }}$ Grade students' conceptual challenges with mathematical symbolization and instructional strategies that teachers use to mitigate mathematical symbolization. The study is motivated by the students' failure to connect representations between symbolic and mathematical ideas to understand concepts and procedures. The study attempts to gain insight into mathematical symbols as potential barriers to students' understanding of mathematical concepts and processes. The study consists of 120 randomly selected $12^{\text {th }}$ Grade students and 15 purposefully selected mathematics teachers from Sekhukhune district of Limpopo Province, South Africa. Data was collected through questionnaires and focus group interviews. A mixed-method sequential explanatory design was employed. An SPSS cluster analysis of data produced three (3) clusters consisting of 50 (41.6\%), $47(39.3 \%)$ and $23(19.1 \%)$ students with severe, mild, and minor challenges with mathematical symbols. Two themes emerged from the students' difficulties with mathematical symbols. Firstly, students lack symbol sense for mathematical concepts and algebraic insight for problem-solving. Secondly, students disregard conceptual and contextual uses of symbols. The study therefore suggests that students' negotiation of discourse between the mathematical symbol and the mathematical concept or procedure is crucial developing symbolic meaning. Therefore, teachers need to use appropriate strategies to engage students in processes that allow them to make meanings of mathematical symbols. The study recommends that concepts should be understood before symbolised.
\end{abstract}

Keywords: Mathematical symbolization. Conceptual understanding. Mathematical contexto. Semiotics.

\section{Resumo}

Este artigo investiga os desafios conceituais dos alunos sul-africanos, do décimo segundo ano, com simbolização matemática e estratégias de ensino que os professores usam para mitigar a simbolização matemática. O estudo é motivado pela falha dos alunos em conectar representações entre ideias simbólicas e matemáticas para entender conceitos e procedimentos. O estudo é uma tentativa de obter insights sobre símbolos matemáticos como barreiras potenciais para a compreensão dos alunos acerca de conceitos e processos matemáticos. O estudo, realizado no distrito de Sekhukhune, da província de Limpopo, África do Sul, abrangeu 120 alunos da $12^{\mathrm{a}}$ série, selecionados aleatoriamente, e quinze professores de matemática, selecionados propositalmente. Os dados foram coletados por meio de questionários e entrevistas com grupos focais. Um projeto explicativo sequencial, de método misto, foi empregado. Uma análise de agrupamento de dados SPSS produziu três (3) agrupamentos, consistindo de 50 $(41,6 \%), 47(39,3 \%)$ e $23(19,1 \%)$ alunos com desafios severos, leves e menores, relativos aos símbolos

\footnotetext{
* Dr, University of South Africa (UNISA). Mathematics Education Lecturer, University of Limpopo (UL), Polokwane, Limpopo Province, South Africa. E-mail: paulmutodi@gmail.com.

** Dr, University of the Western Cape (UWC). Professor of Mathematics Education, University of the Free State (UFS), Bloemfontein, Free State Province, South Africa. E-mail: mosimegemd@ufs.ac.za.
} 
matemáticos. Dois temas emergiram das dificuldades dos alunos com símbolos matemáticos. Em primeiro lugar, os alunos não têm senso de símbolo para conceitos matemáticos e visão algébrica para a resolução de problemas. Em segundo lugar, os alunos desconsideram os usos conceituais e contextuais dos símbolos. O estudo, portanto, sugere que a negociação dos alunos, referente ao discurso entre o símbolo matemático e o conceito ou procedimento matemático, é crucial para o desenvolvimento do significado simbólico. Portanto, os professores precisam usar estratégias adequadas para envolver os alunos em processos que lhes permitam fazer significados de símbolos matemáticos. O estudo recomenda que os conceitos sejam compreendidos antes de simbolizados.

Palavras-chave: Simbolização Matemática. Compreensão Conceitual. Contexto Matemático. Semiótica.

\section{Introduction}

Mathematical symbols are the language in which problem-situations and the solutions are expressed (GODINO; BATANERO; FONT, 2007). Mathematical symbols have a communicative function and an instrumental role (MARACCHIA, 2013). They play an important role in the students' learning of mathematics such as representing concepts, operations, and expressions or equations (MAHARAJ, 2008). Mathematical symbols enable the essence of mathematical thought to be exchanged and shared (GÜÇLER, 2014). However, the way symbolism is used to assist the development of concepts is problematic. Dealing with numbers and algebra presents students with semiotic challenges since symbols act dually a processes and concepts (TALL, 2008).

Students face difficulties in understanding the meaning of symbols if their referents do not represent the mathematical meaning well or if the connection between the referent and the written symbol is not appropriate (KIZILTOPRAK; KÖSE, 2017). Students have trouble constructing meanings for them because they derive meaning of symbols from either connecting with other forms of representations such as physical objects, pictures, or spoken language (YETKIN, 2003). The difficulty in understanding symbols comes from the fact that symbols take on different meanings in different settings and contexts. Adams (2003) noted that students are not aware of meanings of mathematical symbols in different problem contexts. Bardini and Pierce (2015) stated that students are not conversant with the multiple meanings of the mathematical symbols and contexts in which they are used.

Mathematical symbols are the means of representing mathematical concepts as well as communicating mathematical meaning (BRUNER; HASTE, 2010). Mathematical concepts or objects do not have a tangible existence and are not directly accessible to perception. They are only accessed through symbolic representation (FAGNANT, 2005). However, the symbolic nature of mathematics makes it difficult to understand and challenges students. The symbolic language of mathematics is meaningful to teachers but present challenges to students 
(RUBENSTEIN; THOMPSON; 2001). South African students have difficulties in verbalizing, reading, understanding, and writing mathematics to express their mathematical thoughts (PETERSEN; MCAULIFFE; VERMEULEN, 2017). The use of formal algebraic symbols is a barrier to novice algebraic students. The special written symbolism of mathematics proves to be the hardest form of language for students (WASIK, 2012).

Students often come to school with an informal mathematical language that makes it difficult to construct mathematical knowledge. Teachers often view students' informal knowledge as counter hegemonic to the teaching and learning process (O'TOOLE, 2006). One challenge of teaching mathematics is moving students from every day informal ways of construing knowledge into the technical, symbolic, and academic ways that are necessary for disciplinary learning in all subjects (SCHLEPPEGRELL, 2007). Mathematics uses a special and unique symbolic language to construct knowledge. This language has special characters that students must master in order to participate in mathematical discourses. Nagy and Townsend (2012) pointed out that this symbolic language challenges novices in mathematics. Encouraging students to bring their informal knowledge and symbols into the classroom and connecting it to formal mathematics is also a challenge. Teachers struggle to reconceptualize their own thinking of mathematics and to be inclusive of the students' different informal knowledge (MAHER; POWELL, 2013). Teachers disregard students' informal mathematical symbols that can provide insight into the students' conceptual shortcomings and inform the teaching approaches that provide the direction, possible tasks, and questions required to scaffold the learning. However, teachers do not recognize, understand, and interpret students' informal thinking and build around those limitations.

Visual displays in the form of graphs and diagrams are another form mathematical symbolism (HAMMILL, 2010). These representations require students to be able to recognize the meanings in the interaction of these semiotic systems. Mathematical diagrams and graphs provide a connection between the material world and the mathematical processes. One problem of visual representations is that they do not match up exactly with the oral and written language used to develop the meanings they present (MARACCHIA, 2013). O'Halloran (2005) shows that a mathematics problem presented visually requires dense nominal structure when translated into words. Thus, visual, linguistic, and symbolic challenges complicate conceptual understanding in mathematics (LANDY; GOLDSTONE, 2007).

The construction of mathematical knowledge through symbolism occurs during classroom oral interactions. Teachers' words are needed to interpret the meanings that the visual and symbolic representations (SCHLEPPEGRELL, 2007). Textbook explanations are dense, so 
the teacher plays a key role in helping students learn to negotiate meanings for the symbols, diagrams, and technical language. O'Halloran (2005) recommended that teachers should use oral language to unpack and explain the meanings in mathematics symbolism as a way of using the multi-semiotic nature of mathematics to help students draw on the different meaningmaking modes for understanding.

This article is part of a larger study that aims at highlighting the challenges of mathematical symbolization and suggests pedagogical practices to help students in mathematics classrooms. The research also seeks to investigate how mathematical symbols are used to move students from informal ways of mathematics thinking to formal symbolic register, technical, and precise meanings.

\section{Research Focus and Questions}

In an ideal mathematics learning situation, students are expected to be competent in representing mathematical situations and recognizing structure and meaning in symbolic expressions (MOSCHKOVICH, 2008). Learning mathematics with understanding involves acquiring the knowledge of concepts and mastering the skills of encoding the meanings of symbols (RITTLE-JOHNSON; SIEGLER; ALIBALI, 2001). This requires students to be efficient and fluent in using symbols, and manipulating symbols effectively to discover and make new mathematical concepts. However, this is not the case in most South African mathematics classrooms. Many students find mathematical texts overwhelming because of their dense symbolic nature, unfamiliar notations and conventions (NAIDOO, 2016). The dense formulation of mathematical symbolism presents students with challenges to unpack meaning. Consequently, students resort to using symbols without understanding their meanings, but instead they look for an implied procedure inherent in the symbols (ABABNEH; KHASAWNEH, 2020).

Various researchers posted several reasons about students' failure to conceptualize mathematical concepts. One of the difficulties originates from unfamiliar symbols that are confusing and sometimes contradictory (LOMMATSCH; MOYER-PACKENHAM, 2018). Guin, Ruthven and Trouche (2006) revealed that students do not endow mathematical symbols with meaning, understand the context in which they are used as well as recognizing concepts, models, and actions associated with the symbols. Yetkin (2003) made a similar claim and blamed mathematical symbolism as the major obstacle to conceptual understanding. Mathematical symbols also limit students' problem-solving endeavors (HEEFFER, 2012). Tall 
(2008) attributed students' poor symbolic efficacy to the lack of algebraic insight and to the dual roles of symbols as representing mathematical processes or mathematical concepts. Symbolic language remains a challenge for South African students such that teachers continuously pursue effective instructional strategies to curb this problem (PROBYN, 2009). Thus, the problems addressed in this study relate to the nature of challenges that students experience with symbolic representations. The study envisaged the following research questions:

a. What challenges do secondary school students encounter when interpreting and using mathematical symbols to understand mathematical concepts?

b. What instructional strategies do mathematics teachers use to mitigate the obstacles caused by symbols?

The purpose of this study was to obtain insights into students' difficulties with mathematical symbolism. It also examined instructional strategies and practices that teachers use to teach symbolism and address students' shortcomings. The study sought to obtain in-depth understanding of how students perceive mathematical concepts focusing on how they interpret mathematical symbols. The study also sought to sensitize teachers on the need to select instructional activities that support the development of algebra as a sense-making activity.

\section{Theoretical Framework}

The exploration of mathematical symbolization is guided mainly by a combination of the APOS theory (DUBINSKY; WELLER; MCDONALD; BROWN, 2005) and the Procept Theory (GRAY; TALL, 1994). The APOS theory is used in conjunction with the Algebraic Insight framework (PIERCE; STACEY, 2001), as it helps to identify structures by their appearance and key features and insights related to algebra. Under the notion of the Procept Theory lies the symbol sense theory (ARCAVI, 1994), which includes, among other components, the ability to manipulate, read symbolic expressions, and realize that symbols can play different roles in different contexts.

Symbol sense is the ability to use symbols in the interpretation and resolution of mathematical problems (ARCAVI, 2005). It also involves the creative use and interpretation of symbols when describing mathematical situations and problem-solving situations. Furthermore, it encompasses the choice of symbols, the flexible manipulation skills, and symbols in context. Arcavi (1994, p. 25) described it as "making friends with symbols", including an understanding and feel for symbols, how to use them and read them. Henderson, Rasmussen, Zandieh, Wawro 
and Sweeney (2010) characterize symbol sense as an aesthetic feel for the power of symbols including an appreciation of what they can and cannot do, a feeling for when to abandon the use of symbols and turn to other representational forms. Symbol sense also entails the ability to read symbolic expressions and equations, the ability to initiate symbolic forms, and a sense for the different roles that symbols play in different contexts.

Algebraic Insight is the component of symbol sense that helps in the mathematical solution of algebraically formulated problems. The first five attributes of symbol sense apply to the 'solving' section of the Algebraic Insight model (PIERCE; STACEY, 2001). Algebraic insight is a specific symbol sense needed at only the solving stage. Algebraic expectation focuses on the application of Algebraic Insight within the symbolic representation of mathematics while ability to link representations deals with the students' ability to move cognitively between symbolic (algebraic) representations and graphical or numeric representations. Algebraic insight framework addresses ways to plan, assess, and reflect on students' understanding when solving mathematical problems (PIERCE; STACEY, 2001). Incorporating this framework and aspects of symbol sense at all levels of problem-solving assists in identifying students' progress in developing activity-effect relationships. In analyzing students' execution of the activity, the researcher can look for signs of recognition of conventions and properties to identify some of the aspects of symbol sense, including students' understanding of the meaning of symbols and of order of operations. Symbol sense and Algebraic Insight frameworks also blend well since Algebraic Insight is embedded in Symbol Sense.

Procept and APOS are closely related theories that seek to explain how students learn new mathematics content. They are all frameworks of conceptual growth. The implication of the two theories is that students play an active role in their own learning and action is required on their part to develop a deep level of mathematical understanding. Students who do not see an object as more than a procedure may well be good at performing computations and succeed in the short term but in the long term, they may lack the flexibility that will give them greater success. Even though Dubinsky's APOS theory refers to students' mental views and Tall's worlds are about mathematical thinking, the theories seem to blend naturally together. Such a framework allows researchers to evaluate students' conceptual understanding of mathematical symbols and observe the way students learn. Furthermore, it was designed to help teachers and instructors cover a spectrum of representations in the classroom in such a way that teaching based on it would help students build symbolic knowledge and give them the impression that mathematics is not "completely cut, dried, and salted away" (MASON, 2002, p. 4). 
Procept and APOS frameworks are cognitive oriented frameworks that provide useful tools for modelling students' conceptual growth and explain the way students learn new material. APOS is applicable as a tool to questions such as: "What pedagogical strategies can help students in the mental construction of a particular concept?” Learning a new mathematical concept is easy if it involves an action conception of the concept, a process conception of the concept. A student with an object conception of a mathematical concept can think about, name, and manipulate an object without necessarily focusing on how it is being formed. On the other hand, a student with a process conception can think about problem-solving procedures and solution processes with little emphasis on what the object is. From a constructive point of view, the process is more important than the product.

The theoretical frameworks have representation as a common feature. Kaput (2000) describes a representation as a type of relationship between a symbol and its referent. Representation facilitates meaning-making and problem-solving. Each of these theoretical orientations makes an important contribution to the understanding of mathematical symbolization and its contribution to mathematics teaching and learning. The composite conceptual framework is shown in Figure 1 below:

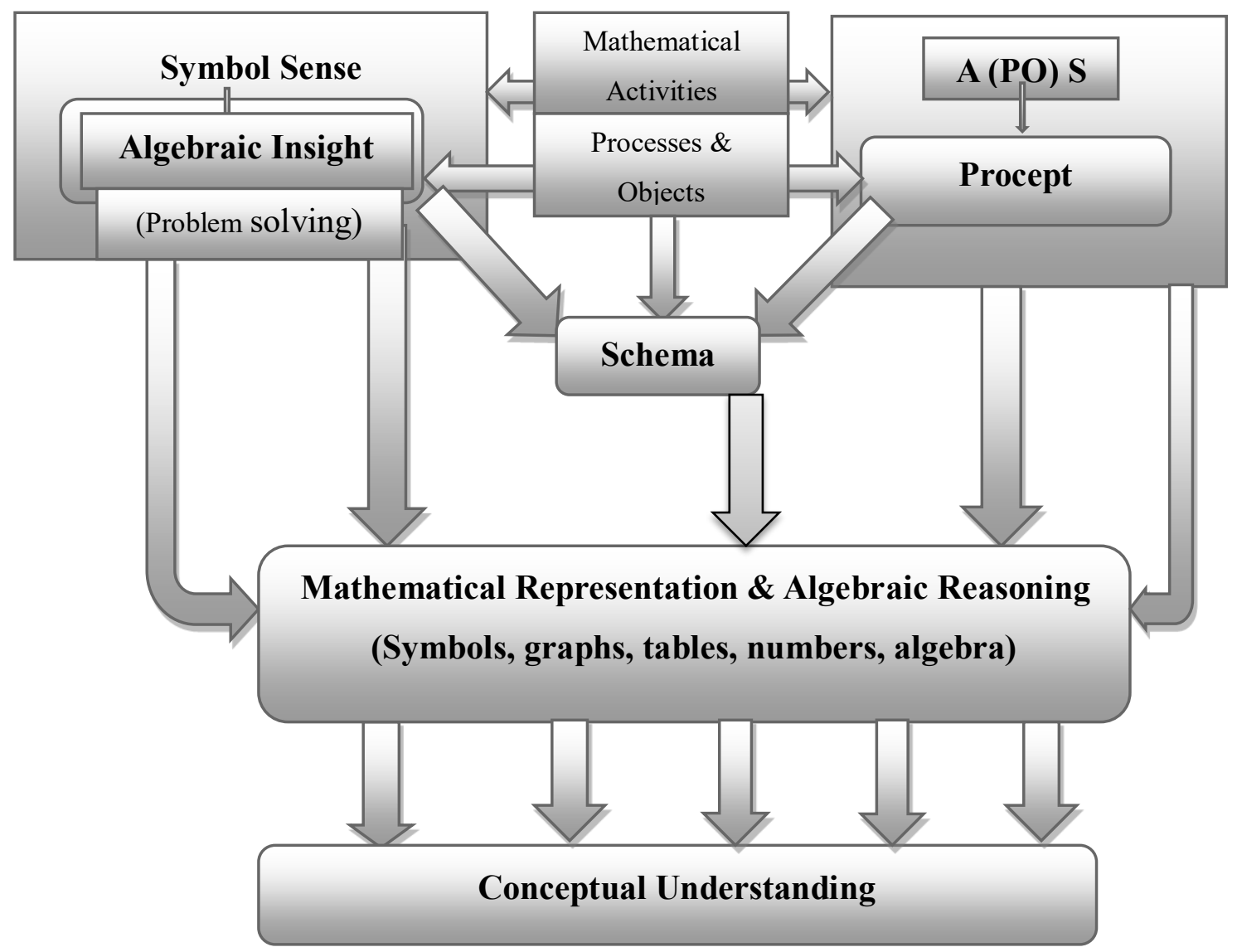

Figure 1 - Symbolisation Theory

Source: Adapted Mutodi (2016) 
Figure 1 shows the theoretical frameworks used (APOS and Symbol Sense) and the relationship between them. The APOS theory characterizes the mathematical knowledge that a student needs to respond to a problematic mathematical situation. Learning occurs by reflecting on the problems and their solutions within a social context and the construction or reconstruction of actions, processes, and objects, organizing them into schemas to deal with this situation (DUBINSKY; MCDONALD, 2001), while symbol sense concerns strategic work with a global focus and emphasis on algebraic reasoning. The two theories help on the formation of a schema for a mathematics concept. A schema is a collection of processes and objects that a student uses to organize, understand, and make sense of mathematical concepts (DUBINSKY, 1994). A schema is an organizing structure that a student invokes to deal with new and unfamiliar mathematical situations (MPHUTHI; MACHABA, 2018). At the schema level, a student develops flexible methods of handling mathematical symbols and notation, which is also a construct of symbol sense notation, and is able to classify mathematical expressions either as a process or as an object.

\section{Methodology}

A mixed methods approach was utilized in this study. The choice of a mixed method approach was derived from the nature of research questions and the kind of instruments used to acquire the data. The first research question for this study seeks to explore the challenges that students encounter when interpreting and using mathematical symbols to understand mathematical concepts. The second research question seeks to explore instructional strategies that teachers use to mitigate mathematical symbolization obstacles. To address these research questions, a survey questionnaire consisting of closed and open-ended questions was used to obtain both quantitative and qualitative data. Quantitative data analysis methods were used to summarize data in the form of descriptive statistics. The questionnaire yielded several categories of problems that students experienced. The categories were later explored in the focus group interviews. The findings from the two analyses were later triangulated.

\subsection{Population and Sampling}

The target population consists of $12^{\text {th }}$ Grade students and teachers in Sekhukhune Districts of Limpopo Province. Mathematics teachers were deemed as valuable sources of data regarding the challenges of mathematical symbolization since they observe students' challenges 
during teaching and learning. Multi-stage sampling was used to select participating circuits, schools, and students while teachers were purposively selected. The sample for the study consists of $12012^{\text {th }}$ Grade students and 15 mathematics teachers.

\subsection{Research Instruments}

In this study, questionnaires and focus group interviews were used to solicit data from participants. The questionnaire consisted of 26 closed-ended items about challenges with mathematical symbols on a 5-point Likert scale, wherein, $1=$ strongly disagree, $2=$ disagree, $3=$ neutral, and $4=$ agree and $5=$ strongly agree. The items of the questionnaires were derived from research objectives and research questions. The questionnaire consisted of a mixture of closed-ended and open-ended questions. Closed-ended questionnaires are more convenient because of their ease of analysis (SELIGER; SHOHAMY, 1989) while open questions can lead to a greater level of discovery (GILLHAM, 2000), because participants can express what they want to say (ZOHRABI, 2013). Focus group interviews also allow participants to be motivated to think by responses from other participants (O'NYUMBA; WILSON; DERRICK; MUKHERJEE, 2018). A pilot survey was conducted to assess the feasibility of the study and pre-testing research instruments (BAKER, 1994). Out of 120 participants, forty-eight (48) were purposefully selected based on their responses to closedended questions for focus group interviews. Focus groups consisted of 12 students per group and discussions went on until no new information emerged from students' narrations of their experiences or difficulties with mathematical symbolization.

\subsection{Data Collection}

Data were collected through questionnaires and focus group interviews. To ensure validity and reliability of self- constructed questions, research instruments were pilot tested to assure their adoption in the study (BOLARINWA, 2015). The questionnaire consists of 26 closed questions (coded $\mathrm{C} 1-\mathrm{C} 26$ ) with a 5-point Likert scale ranging from strongly disagree to strongly agree and 10 open-ended questions. The researcher personally administered the questionnaire to the participants at their schools. This had a fast and high response rate, as the researcher could get the questionnaires completed quickly as compared to the postal method, where participants might postpone responding or questionnaires are delayed in transit (SEKARAN; BOUGIE, 2016). The meanings of the questions were clarified to ensure that the 
participants were answering the questions in the sense that the researcher intended. Focus group interviews were held with 48 participants (four groups of 12) who were purposefully selected based on their responses to the closed-ended questions. The discussions were mainly centered on predictor variables such as C23, C18, C21, C24, and C15 (see table 2). These variables emerged as nodes and leads that were interrogated further to shed more light on students' challenges with mathematical symbolization.

\section{Data Analysis}

The data was analyzed using Statistical Package for Social Sciences (SPSS) version 23. A mixed analysis strategy was used to analyze the data. The rationale for conducting the mixed analysis was to ensure that results from one analysis type (qualitative) are interpreted to enhance or expand, findings derived from the other strand (quantitative). The study adopted a sequential explanatory analysis of qualitative and quantitative analyses guided by Creswell and PlanoClark (2007)'s procedure for analyzing mixed data. Data was analyzed quantitatively and qualitatively. Quantitative data analysis involved descriptive (frequency tables, clusters) and inferential statistics (Silhouette measures and tests of hypothesis, T- and ANOVA tests). Qualitative data analysis utilized cluster nodes generated from cluster analysis as well as interview data from both teachers and students to create typologies or categories of mathematical symbolization challenges and pedagogical strategies. Interview transcripts were content analyzed to generate themes. Thematic analysis was conducted to identify themes and patterns of meaning across the dataset in relation to research questions. The process involves searching for themes among categories, reviewing themes, defining and naming themes, and validating the themes.

Validation of themes was done by going back to most interviewees to let them see their response "or themselves" in the themes. Their agreement with the themes meant validity was established. In case of disagreements, we would revisit our codes and transcripts to re-read and revise our interpretation. The new themes would have to be validated again until there was a majority agreement.

Another approach to validation was to present the themes to people with the same experience in mathematics but were not included in the actual interview. This tested the generalizability of themes. Expert qualitative researchers also verified the themes if they agreed with scholarly interpretation. This validation of themes is also in accordance with Colaizzi's technique of qualitative data analysis (WIRIHANA; WELCH; WILLIAMSON; 
CHRISTENSEN; BAKON; CRAFT, 2018).

\subsection{Cluster Analysis}

The first step in cluster analysis involved medoid clustering of closed questions in questionnaire. Participants were required to indicate the extent to which they agreed or disagreed with the given statements in relation to their experiences with learning mathematical concepts through symbolization. Cluster analysis classified the data set into groups, and it provided an automatic selection of number of clusters (ABONYI; FEIL, 2007). Cluster analysis assumes that the sample is large $(n>100)$, this criterion was met since the sample size for this study was 120 .

\subsection{Two-Step Cluster analysis Results}

Table 1: Cluster analysis results

\begin{tabular}{|c|c|c|c|c|}
\hline Algorithm & Inputs & Clusters & Cluster Quality & Silhouette value \\
\hline Two-step & 26 & 3 & Good & 0.55 \\
\hline
\end{tabular}

Source: Mutodi (2016)

The summary in Table 1 shows decomposition of 26 inputs into three clusters. A twostep cluster analysis algorithm was used to obtain a Silhouette measure of cluster cohesion and separation of 0.55 , which indicates a good cluster quality since it falls in the interval $[-1,+1]$ (SALO; SALMI; CZINK; VAINIKAINEN, 2005; LAROSE, 2014). 


\subsection{Predictor Importance Nodes}

Table 2: Importance predictor nodes

\section{Nodes}

$\mathrm{C} 23$

C18

$\mathrm{C} 21$

$\mathrm{C} 24$

$\mathrm{C} 15$

$\mathrm{C} 20$

C19

$\mathrm{C} 13$

$\mathrm{C} 22$

$\mathrm{C} 16$

\section{Description}

Switching representations using appropriate symbols

Symbols obscure conceptual understanding

Symbols affect problem solving

Symbol meanings are a challenge during problem solving

Flexibility with mathematical symbols

Mathematical symbols are not satisfying to use

Unfamiliar symbols obscure conceptual understanding

Informal symbols and formal symbols are contradictory

Symbols affect problem solving processes

Symbols affect problem solving goals

\section{Importance value}

1

0.8744

0.6946

0.6927

0.6618

0.6546

0.5841

0.5661

0.5643

0.5173

Source: Mutodi (2016)

During data analysis, participants' responses were ranked according to an importance predictor values scale. Table 2 shows that variables C23, C18, C21, C24 and C15 have a significant effect on the students' understanding of mathematical concepts together with their symbols while the least important variables were $\mathrm{C} 4, \mathrm{C} 10, \mathrm{C} 9$ and $\mathrm{C} 8$, although they were not indicated in the table. The importance values of the 10 most predictor variables are shown in the Table 2.

Table 2 shows the predictor importance values of the most dominant variables in the data set. These nodes were used as leads for thematic analysis during categorization of qualitative data. Interview questions were also built around these nodes. Thus, the three clusters suggested by the model were based on C23, C18, and C21. Participants indicated that the most challenging aspect of mathematical symbolization was switching representations using the appropriate symbols, moving from geometric representations to geometric or vice versa. Students indicated that mathematical symbols are abstract and lack one to one correspondence with real world object they represent. This is consistent with Pimm (2002), who found that some mathematical concepts do not have real world representations that portrays them. A thematic analysis of teachers' interviews was done to identify patterns of themes in the interview data. Teachers confirmed that it is difficult to provide representations from the real world that can illuminate mathematical abstractions, and it is their responsibility to identify such representations and use them to assist conceptual understanding. Teachers should form a strong 
association between mathematical symbols and their meaning.

Another challenge raised by students was that mathematical symbols obscure conceptual understanding (C18). In particular, students indicated that symbols obscure them from understanding mathematical concepts. This observation confirms that students find it difficult to associate symbols with related concepts. Teachers blamed the curriculum for lacking emphasis on teaching strategies that equip students with strong conceptual and symbolic understandings in order to make conceptual sense of the mathematical concepts.

Students indicated that symbols present them with challengers during problem-solving (C21). They reported that they experience challenges in using symbols productively in problemsolving. They also indicated that they are not capable of making sense of some symbols in problem situations. Thus, students lack skills of abstracting mathematical situations, representing them symbolically and manipulating symbols without attending to their referents. This indicates students lack symbol sense.

\subsection{Cluster Distribution}

Table 3 below summarizes the information in the SPSS output table.

$\begin{array}{cccc}\text { Cluster } & \begin{array}{c}\text { Table 3: Cluster distribution frequencies } \\ \text { Cluster Size (N) }\end{array} & \begin{array}{c}\text { \% of Combined } \\ \text { \% of Total }\end{array} \\ \text { Cluster 1 } & 47 & 39.3 \% & 39.3 \% \\ \text { Cluster 2 } & 50 & 41.6 \% & 41.6 \% \\ \text { Cluster 3 } & 23 & 19.1 \% & 19.1 \% \\ \text { Total } & 120 & 100 \% & 100 \%\end{array}$

Source: Mutodi (2016)

Table 3 above shows cluster sizes suggested by the model. The smallest cluster (cluster $3)$ has a size of $23(19.1 \%)$ students. Cluster 2 has a size of $50(41,6 \%)$ while cluster 1 has a size of $47(39.3 \%)$. The ratio of the largest cluster to the smallest cluster was 2.18 . This ratio indicates that there are at least twice the numbers of students who experience challenges with mathematical symbolism than those who are competent and comfortable using symbols.

The following clusters of students emerged:

\subsubsection{Cluster 1}

Cluster one is made up of 47 participants (39.3\%) in the sample, consisted mainly of 
students who indicated that they have limited instances of symbol sense. Participants who fall in this cluster indicated they have partial competence with mathematical symbols and can switch representations from one form to another. It also consists of students who have mild difficulties in doing mathematical tasks despite lack of proficiency in symbol use.

\subsubsection{Cluster 2}

This is the largest cluster made up of 50 participants (41.6\%) containing mostly students who indicated that they strongly agree that they experience challenges in handling, manipulating, and using mathematical symbols to understand mathematical concepts. The cluster consisted of students who struggle to switch representations from one form to another. Participants in this cluster indicated that they struggle to do mathematical tasks due to lack of proficiency in symbol use. Members of this cluster also indicated that symbols in a mathematics problem have a strong influence on their attempt to solve the problem. Another difficulty raised by students in this cluster is that they struggle to initiate symbols in order to solve problems. Another difficulty associated with students in this cluster is the lack of flexibility to switch from one formula/structure to another in relation to the task demands and symbols used in a mathematics problem. Students in this cluster could not link symbolic and algebraic representations to graphical forms. Thus, the 50 students $(41.9 \%))$ in cluster 2 lack symbol sense as most of the aspects in this cluster indicate instances of symbol sense.

\subsubsection{Cluster 3}

The third cluster, which is made up of 23 participants (19.1\%), contains mostly a mixture of students whose understanding of mathematical concepts and symbols ranges from agree to strongly agree. Students in this cluster indicated that they can confidently handle/manipulate mathematical symbols with understanding. Participants indicated that the symbols in a mathematical problem have a significant influence on their attempt to solve a mathematics problem. The cluster also contains students who understand mathematical concepts and can initiate symbols to solve problems, including specifying units and distinguishing among the three main uses of variables (unknowns, placeholders, parameters). Students in this cluster are also flexible to move from one formula to another in relation to the demands of task and the symbols used in the question and formulae do not affect their understanding of concepts. Thus, out of the 120 students surveyed only 23 do not have severe difficulties with mathematical 
symbols, instead symbols to them are tools to aid understanding.

\section{Discussion}

The study highlighted the importance of paying attention to potential barriers to students' learning because of complex symbols used to represent mathematical concepts and processes. As highlighted by Bardini and Pierce (2015) mathematical symbols form the foundation of mathematical communication, hence students should comprehend them and associate them with meaning. The study conjecture that symbol load, unfamiliarity, and increased density may cause present students with challenges when learning mathematics. Extensive research on students' understanding of mathematical symbols at secondary level revealed that symbols 'conciseness and abstraction can be a barrier to learning, and this research contributes to that debate by bringing additional dimension of the time needed to master certain symbols and lack of proper instructional strategies to promote competence with mathematical symbols. For teachers, mitigating the challenges of mathematical symbolism is still an issue that is not easy to add in their teaching. The transition to new symbols and concepts requires teachers to alert students about the diversity of symbols as well as the varieties of their meaning in different contexts.

\section{Conclusion}

The data for this study present two major findings. Firstly, students indicate that there are challenges connected to the use of mathematical symbols when learning mathematical concepts. Teachers also indicated that mathematical symbols present pedagogical challenges when teaching mathematics. They indicated that the intertwined nature of mathematical symbolism and mathematical understanding present learning challenges but suggest that meaning must precede symbolization. Thus, students should be involved in contexts, problems, and activities that move them from familiar to newer mathematical ideas. Students indicated that mathematical symbols obscure them from understanding mathematical concepts and to present solutions to problems. Most students confirmed that some symbols are not familiar, and they struggle to associate them with the embedded mathematical concepts. Students revealed that navigating through the symbols and their meanings is a complex process due to multiple meanings of some symbols. Consequently, this makes Algebraic topics and rules for manipulating and combining them unpopular. An important issue emerging from the study is 
that the majority of the students lack the ability to generate symbols and use them in problem solving. By so doing, students showed a lack of symbol sense. The study showed that students' poor understanding of mathematical symbols is attributed by unfamiliar symbols. Misconceptions and poor conceptions in the interpretation of mathematical symbol result in students failing to link mathematical symbols and formulae with appropriate concepts. Thus, the challenges raised in the study reveal that teachers do not reflect and devise teaching approaches that promote conceptual understanding and representational efficacies. Thus, classroom interactions should focus on making sense of mathematical symbols, rules, and formulae to assist students in developing meaningful understanding of mathematical concepts.

Another challenge raised by students was that the symbolic representation of mathematics concepts is abstract and therefore difficult to learn. This shows students have not yet acquired the abstract level of mathematical thinking and use of higher order skills for mathematical thinking. Teachers should therefore nurture the development of students' symbol sense in order to accommodate new mathematics cognitive demands. Teachers tend to encourage students to manipulate symbols without the proper conceptual foundation that limits their progress into higher mathematics.

The study also observed that instructional strategies to curb mathematical symbolization challenges are not yet available, and teachers are still in the trying phase. Learning of mathematics is hindered by the use of unfamiliar notation. Learning resources such as textbooks do not explain to students' satisfaction due to language challenges. Students' work is characterized by meaningless symbol manipulation. Students use symbolic expressions without understanding their meanings. These difficulties in learning written symbols can be reduced by creating learning environments that help students build connections between their formal and informal mathematical knowledge, using appropriate representations depending on the given problem context. Therefore, teachers should be aware of these difficulties and provide students with opportunities to recognize the patterns and make connections within the symbol system.

Students indicated that textbooks use unfamiliar symbols and notations that are difficult to understand. They are relevant and make sense after the teacher explanations. The flow of mathematical concepts is not linear. Reading a mathematics textbook requires careful understanding of each word as suggested by Pimperton and Nation (2010). Textbooks do not consider the students' background knowledge. Reading mathematics text requires students to be active and competent users of mathematics textbooks, including all parts of textbooks. There is a need for teachers to make reading an integral part of mathematics instruction. 


\section{Implications}

The implication for mathematics teaching and learning drawn from the study is that before students are required to use and manipulate mathematical concepts, the meanings of the symbols must be established. This should be done when new topics are introduced and the context in which the symbols are used should be clarified. Once meanings are established for symbols, it is possible to think about creating meanings for rules and procedures that govern actions on these symbols. The transition from arithmetic to algebra requires students to have a strong symbol sense. This requires teachers to focus students' attention to how they build meanings for algebraic concepts and processes. Teachers should guide students in seeing algebraic symbols as tools for thinking, as mathematics concepts, and as processes.

\section{References}

ABABNEH, M. A. R.; KHASAWNEH, A. A. Symbol Sense Among Undergraduate Students. Journal of Al-Quds Open University for Educational \& Psychological Research \& Studies, Palestine, v. 11, n. 32, p. 102-120, dec. 2020.

ABONYI, J.; FEIL, B. Cluster analysis for data mining and system identification. Berlin: Springer Science \& Business Media, 2007.

ADAMS, T. L. Reading mathematics: More than words can say. The Reading Teacher, Newark, v. 56, n. 8, p. 786-795, may. 2003.

ARCAVI, A. Symbol sense: Informal sense making in formal mathematics. For the learning of Mathematics, Hamburg, v. 14, n. 3, p. 24-35, nov. 1994.

ARCAVI, A. Developing and using symbol sense in mathematics. For the learning of mathematics, Hamburg, v. 25, n. 2, p. 42-47, jul. 2005.

BAKER, T. L. Doing social research. 2. ed. New York: McGraw-Hill, may. 1994.

BARDINI, C.; PIERCE, R. Assumed mathematics knowledge: the challenge of symbols.

International Journal of Innovation in Science and Mathematics Education, Bhopal, v. 23, n. 1, p. 1-9, feb. 2015.

BOLARINWA, O. A. Principles and methods of validity and reliability testing of questionnaires used in social and health science researches. Nigerian Postgraduate Medical Journal, Ilorin, v. 22, n. 4, p. 195-201, oct. 2015.

BRUNER, J. S.; HASTE, H. (Eds.). Making Sense (Routledge Revivals): The Child's Construction of the World. New York: Routledge, 2010.

CRESWELL, J. W.; CLARK, V. L. P. Designing and conducting mixed methods research. Wiley Online Library, 2007.

DUBINSKY, E.; MCDONALD, M. A. APOS: A constructivist theory of learning in undergraduate mathematics education research. In: HOLTON, D. (Ed.). The teaching and learning of mathematics 
at university level 2001. Dordrecht: Springer, 2001. p. 275-282.

Dubinsky, E. A theory and practice of learning college mathematics. In: SCHOENFELD, A. (Ed.). Mathematical Thinking and Problem Solving. Hillsdale: Erlbaum, 1994. p 221-243.

DUBINSKY, E.; WELLER, K.; MCDONALD, M. A.; BROWN, A. Some historical issues and paradoxes regarding the concept of infinity: An APOS analysis: Part 2. Educational Studies in Mathematics, Berlin, v. 2, p. 253-266, mar. 2005.

FAGNANT, A. The use of mathematical symbolism in problem solving: An empirical study carried out in grade one in the French community of Belgium. European Journal of Psychology of Education, Berlin, v. 20, n. 4, p. 355-367, dec. 2005.

GILLHAM, B. Case study research methods. London: Bloomsbury Publishing, 2000.

GODINO, J. D.; BATANERO, C.; FONT, V. The onto-semiotic approach to research in mathematics education. International Journal on Mathematics Education (ZDM), Berlin, v. 39, n. 1-2, p. 127135, mar. 2007.

GÜÇLER, B. The role of symbols in mathematical communication: the case of the limit notation. Research in Mathematics Education, v. 16, n. 3, p. 251-268, 2014.

GRAY, E. M.; TALL, D. O. Duality, ambiguity, and flexibility: A "proceptual” view of simple arithmetic. Journal for research in Mathematics Education, Reston, VA, v. 25, n. 2, p. 116-140, mar. 1994.

GUIN, D; RUTHVEN, K.; TROUCHE, L. (Eds.). The didactical challenge of symbolic calculators: turning a computational device into a mathematical instrument Berlin: Science \& Business Media, v. $36,2006$.

HAMMILL, L. The interplay of text, symbols, and graphics in mathematics education.

Transformative Dialogues: Teaching \& Learning Journal, Surrey, BC, v. 3, n. 3, p. 1-8, mar. 2010.

HEEFFER, A. Surmounting obstacles: circulation and adoption of algebraic symbolism. Philosophica (Gent), Ghent, v. 87, n. 4, p. 5-25. dec. 2012.

HENDERSON, F.; RASMUSSEN, C.; ZANDIEH, M.; WAWRO, M.; SWEENEY, G. Symbol sense in linear algebra: A start toward eigen theory. In: BROWN, S.; LARSEN, S.; MARRONGELLE, K.; OEHRTMAN, M. (Eds.). Proceedings of the $\mathbf{1 4}^{\text {th }}$ Annual Conference for Research in Undergraduate Mathematics Education. Portland: Oregon, 2010. p. 1-12.

KAPUT, J. J. Teaching and Learning a New Algebra with Understanding. Washington: National Science Foundation, may. 2000.

LANDY, D.; GOLDSTONE, R. L. How abstract is symbolic thought? Journal of Experimental Psychology: Learning, Memory, and Cognition, Washington, DC, v. 33, n. 4, p. 720-733, july. 2007.

LAROSE, D. T. Discovering knowledge in data: an introduction to data mining. New Jersey: John Wiley \& Sons, 2014.

LOMMATSCH, C. W.; MOYER-PACKENHAM, P. S. Learning Logic: examining the effects of context ordering on reasoning about conditionals. International Journal of Mathematical Education in Science and Technology, London, v. 15, n. 5, p. 730-753, june. 2018.

MAHARAJ, A. Some insights from research literature for teaching and learning mathematics. South 
African Journal of Education, Pretoria, v. 28, n. 3, p. 401-414, nov. 2008.

MAHER, C. A.; POWELL, A. B. Research on informal mathematics learning. Investigations in Mathematics Learning, Greensboro, NC, v. 7, v. 2, p. 36-44, may. 2013.

MARACCHIA S. The importance of symbolism in the development of algebra. Lettera Matematica, Berlin, v.1, n. 3, p. 137-44, oct. 2013.

MASON, J. H. Mathematics Teaching Practice: Guide for university and college lecturers. West Sussex: Elsevier, mar. 2002.

MOSCHKOVICH, J. N. "I went by twos, he went by one": Multiple interpretations of inscriptions as resources for mathematical discussions. The Journal of the Learning Sciences, London, v. 17, n. 4, p. 551-587, oct. 2008.

MPHUTHI, G. T.; MACHABA, M. F. An Apos Exploration of the Conceptual Understanding of Algebraic Expressions. Pretoria: ISTE, 2018.

NAGY, W.; TOWNSEND, D. Words as tools: Learning academic vocabulary as language acquisition. Reading Research Quarterly, New Jersey, v. 47, n. 1, p. 91-108, jan. 2012.

NAIDOO, J. Language matters! Exploring promise's use of pedagogic strategies in her mathematics classroom. Language Matters, Pretoria, v. 47, n. 3, p. 372-792, sept. 2016.

O'NYUMBA, T.; WILSON, K.; DERRICK, C. J. MUKHERJEE, N. The use of focus group discussion methodology: Insights from two decades of application in conservation. Methods in Ecology and evolution, London, v. 9, n. 1, p. 20-32. jan. 2018.

O’HALLORAN, K. L. Mathematical Discourse: Language, Symbolism and Visual Images. London: Continuum, 2005.

O'TOOLE, T. Building powerful understanding by connecting informal and formal knowledge. In: GROOTENBOER, P.; ZEVENBERGEN, R.; CHINNAPPAN, M. (Eds.). Proceedings of the 29 $^{\text {th }}$ Annual Conference of the Mathematics Education Research Group of Australasia, Adelaide. MERGA, 2006. v. 2. p. 384-391.

PETERSEN, B. S.; VERMEULEN, C. Writing and mathematical problem solving in Grade 3. South African Journal of Childhood Education, Johannesburg, v. 7, n. 1, p. 1-9, jun. 2017.

PIERCE, R.; STACEY, K. A framework for algebraic insight. In: BOBIS, J.; PERRY, B.;

MITCHELMORE, M. (Eds.) Numeracy and Beyond: Proceedings of the twenty-fourth annual conference of the Mathematics Education Research Group of Australasia. Sydney: MERGA. 2001. v. 2. p. $418-425$.

PIMM, D. Symbols and meanings in school mathematics. Oxford: Routledge, 2002.

PIMPERTON, H.; NATION, K. Understanding words, understanding numbers: An exploration of the mathematical profiles of poor comprehends. British Journal of Educational Psychology, London, v. 80 , n. 2 , p. $255-268$, june. 2010.

PROBYN, M. 'Smuggling the vernacular into the classroom': conflicts and tensions in classroom codeswitching in township/rural schools in South Africa. International Journal of Bilingual Education and Bilingualism, London, v. 12, n. 2, p. 123-136, mar. 2009.

RITTLE-JOHNSON B.; SIEGLER. R. S.; ALIBALI, M. W. Developing conceptual understanding and 
procedural skill in mathematics: An iterative process. Journal of educational psychology, London, v. 93, n. 2, p. 346-362, june. 2001.

RUBENSTEIN, R. N.; THOMPSON, D. R. Learning mathematical symbolism: Challenges and instructional strategies. The Mathematics Teacher, Reston, VA, v. 94, n. 4, p. 265-271, apr. 2001. SALO, J.; SALMI, J.; CZINK, N.; VAINIKAINEN, P. Automatic clustering of nonstationary MIMO channel parameter estimates. Cape Town: ICT'05, may. 2005.

SCHLEPPEGRELL, M. J. The linguistic challenges of mathematics teaching and learning: A research review. Reading \& Writing Quarterly, London, v. 23, n. 2, p. 139-159, feb. 2007.

SEKARAN, U.; BOUGIE, R. Research methods for business: A skill building approach. London: John Wiley \& Sons, 2016.

SELIGER, H. W.; SHOHAMY, E. G. Second language research methods. London: Oxford University Press, 1989.

TALL, D. The transition to formal thinking in mathematics. Mathematics Education Research Journal, London, v. 20, n. 2, p. 5-24, sep. 2008.

WASIK, B. H. (Ed.). Handbook of family literacy. New York: Routledge, 2012.

WIRIHANA, L.; WELCH, A.;WILLIAMSON, M.; CHRISTENSEN, M.; BAKON, S.; CRAFT, J. Using Colaizzi's method of data analysis to explore the experiences of nurse academics teaching on satellite campuses. Nurse Researcher, Alphen aan den Rijn, v. 25, n. 4, p. 30- 36, mar. 2018.

KIZILTOPRAK, A.; KÖSE, N. Y. Relational thinking: The bridge between arithmetic and algebra. International Electronic Journal of Elementary Education, v. 10, n. 1, p. 131-145, oct. 2017.

YETKIN, E. Student Difficulties in Learning Elementary Mathematics. Bloomington, IN: ERIC Digest, 2003.

ZOHRABI, M. Mixed method research: Instruments, validity, reliability and reporting findings.

Theory and Practice in Language Studies, Helsinki, v. 3, n. 2, p. 254-262, feb. 2013.

Submetido em 07 de Junho de 2020. Aprovado em 15 de Fevereiro de 2021. 